\title{
A KÜLFÖLDI TÖKE ÉS A MULTINACIONÁLIS CÉGEK SZEREPE ÉS A GAZDASÁGRA GYAKOROLT HATÁSA MAGYARORSZÁGON
}

\author{
Tóth-Kmoskó Éva \\ Villeroy\&Boch Magyarország Kft.
}

SUMMARY

Presence of the international companies, alien properties, and the foreign capital in Hungary is under a wide social debate. It is the foreign capital which established Hungary's long-range development and this capital will significantly influence it in the future, too. After the political transformation reintegration into the world economy, establishment of market economy and modernization of the economic structure realized by foreign investments implied an outstanding potential for further development.

However, by today the capital drawing ability of Eastern Europe, and Hungary has declined as a result of which adaption to the new situation, reversal of this trend, our ability to keep the capital, and giving the chance to companies in home property all are of stressed importance.

I could conclude that it is absolutely necessary to improve the capital attracting ability of Hungary from the aspect of her future development.

It is necessary to become specialized in new fields, in activities which need labour force of high qualification, for example we can aim at location of service, financial and administrative centres within the company groups to our country.

It is important to increase the efficiency of subventions. Besides, it is advisable to pay attention to regional development if we want prevent companies from leaving our country after that the subventions have been finished.

We should pay more attention to the soft factors of capital attraction. It is necessary to consider what qualitative and quantitative conditions a given area has for example, in the fields of life quality, education and culture.

\section{BEVEZETÉS}

A posztszocialista országokban - köztük hazánkban is - a 80-as éves végén jelentek meg az első külföldi beruházók. Európa keleti blokkjának felzárkóztatása a külföldi tökebefogadás által, azaz a multinacionális vállalatok térhódításával kezdődhetett el. A folyamat kibontakozását jelentősen elösegitette egyrészt a globalizáció, másrészt pedig a potenciális tökefogadó országok gazdaságpolitikája. Utóbbi jelentösen elősegitheti, vagy éppen bizonyos keretek között fékezheti a világgazdasági átalakulás hatásait. A következőkben a Magyarországra érkező külföldi tökebeáramlás jellemző mozzanatait és annak hatásait veszem górcső alá.

\section{KÜLFÖLDI MÜKÖDŐ-TÖKEBEÁRAMLÁS A RENDSZERVÁLTÁSTÓL AZ 1990-ES ÉVEK VÉGÉIG}

Hazánkban a rendszerváltás elött a nemzetköziesedés fogalma jórészt kimerült a KGST-országokkal folytatott sajátos kapcsolatrendszerben és a külföldi tőkebefektetés szerepe minimális volt.

A rendszerváltás azonban mérföldkövet jelentett, mivel a korábbi gazdasági kapcsolatok minöségileg megváltoztak, szinte korlátlan lehetöségek nyiltak a nemzetközi cégek számára ahhoz, hogy nálunk termelö- és szolgáltató vállalkozásokat épitsenek ki. (Simai 2007)

Ha a 90-es éveket vizsgáljuk, akkor megállapítható, hogy hazánkba a legtöbb tökét a németországi vállalatok hozták, elsősorban az energetikai privatizációban történö jelentős részvételnek köszönhetően. Az Egyesült Államok is jelentős részt vállalt a zöldmezős beruházásokból. (General Electric, General Motors, Ford, Guardin Glass). 
Emellett megjelentek osztrák, francia, holland, olasz befektetök is.

A külföldi tőke elöször jellemzöen Budapest és környékére, valamint ÉszakDunántúlra koncentrálódott, ugyanakkor némileg teret nyert az autópályákhoz közeli térségek, így Északkelet-Magyarország (TVK, Borsodchem, Alkaloida) és a keleti országrészben Gödöllö, valamint Kecskemét. (Diczházi 1998)

A fejlett piacgazdaságokba való integrálódás fontos tényezöje a direkt tökeimport, mely a GDP-re is nagy befolyással van, hiszen közvetlenül megvalósul a fejlett technika átültetése és a tökeimport mellett megjelenik a modern vállalatirányitás. A multinacionális vállalatok már meglévő kapcsolataiknak köszönhetően nagyon jó eredménnyel büszkélkedhetnek a külpiacok megszerzésében. Mindezek fontos szerepet játszanak abban, hogy a tranziciós pályára lépö ország relativ magas fenntartható növekedési ütemet képes elérni, akár egy-két évtizedes időtávlatban is.

1997-re, vagyis a meginduló növekedés kezdetére a magyar gazdaságba beáramló müködő tőke állománya 15,5 milliárd dollárt tett ki, ami '97-es dollárárfolyamon számítva a GDP 42\%-át jelentette. Ekkorra Magyarország elveszítette vezetö helyét a direkt tőkeimportállomány abszolút nagyságát nézve a volt szocialista országok között, de az egy före jutó összes direkt import, valamint a direkt tőkeimport GDP-re vetített arányában még mindig vezető helyet foglalt el.

A kezdeti időszakban a feldolgozóiparba irányult a tökeimport több mint fele, de 1997-re ez az arány megváltozott, mivel a szolgáltató szektor szívta el a nagyobb import tökét, ekkorra a súlya $59 \%$-ot tett ki.

Mindez a növekedés ütemét jelentősen befolyásolta, hiszen az exportdinamika a feldolgozóiparban eleinte lényegesen nagyobb volt, mint a tercier szektorban. A technikai fejlödés mára már a szolgáltatási szektorban is jelentős, ezért ez a terület is jelentösen befolyásolja a hosszú távú fejlödést. Azt is érdemes megfontolás alá venni, hogy a viszonylag magas növekedési ütem a tranzíciós pályán a követő gazdaságban mindig nagyobb, mint a vezető gazdaságé. (Erdös 2003)

\section{KÜLFÖLDI MÜKÖDŐ-TŐKEBEÁRAMLÁS AZ EZREDFORDULÓ UTÁN}

Ha a müködő töke-beáramlási folyamatot hosszabb távon, azaz 1990. és 2009. év között vizsgálom, akkor már hazánkban a külföldi müködő tőke állománya meghaladja az 58 milliárd eurót.

A Magyarországra érkező közvetlen külföldi tökebefektetések 2000-töl 2008-ig tartó éves megoszlását az alábbi oszlop-diagram tartalmazza, melyböl kitünik, hogy a 2007. év kiemelkedö volt az 58457 millió eurós összegével. 2008-ban a tökeállomány csökkenése egyértelmüen a külföldi tökekivonásnak köszönhető. A diagramból az is jól lekövethetö, hogy a növekedés 2007 -ig folyamatos, addig a vizsgált időszakban a beáramlott töke több mint duplájára növekedett, majd némi visszaesést követően 2009-ben majdnem elérte a 2007. évi szintet az 58420 millió euró összeggel. 


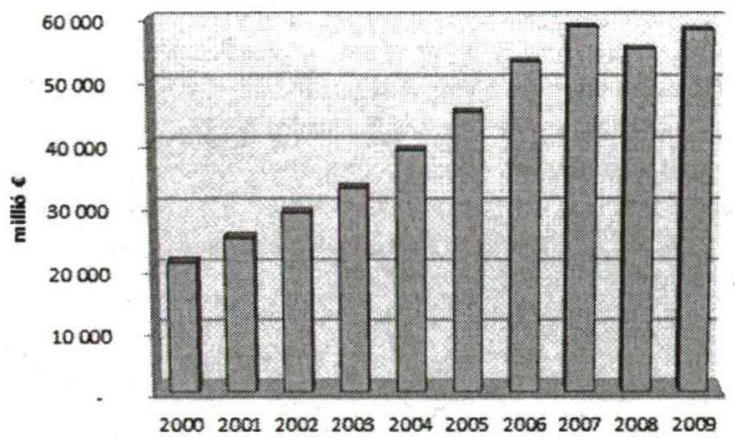

\section{1. ábra. A magyarországi közvetlen külföldi tőkebefektetések állományának alakulása 2000-töl 2009-ig.}

Forrás: Magyar Nemzeti Bank 2011 alapján saját szerkesztés

A 90-es évekre jellemzö magas német befektetési arány Magyarországon 2009-re is megmaradt, hiszen az összes külföldi tőkebefektetésből ez az ország $25,4 \%$ részt vállalt. 2000-től 2009-ig vizsgálódva az is megállapitható, hogy a közvetlen tökebefektetések nagy része Európából származik, mivel ez az arány az évek során $79-84 \%$ között mozgott. A német tőke (25\%) mellett kiemelkedő a holland $(14,57 \%)$, az osztrák $(12,87 \%)$, a francia $(5,67 \%)$, a luxemburgi $(5,01 \%)$ és az amerikai $(3,65 \%)$ részarány.

2009-ban is fennmaradt az ezredfordulón már megfigyelhető tendencia, hogy a szolgáltató ágazatok szívták fel a beáramló külföldi tőke több mint felét. A szolgáltató ágazatokba irányult a külföldi töke nagy része $(64,9 \%)$, nem is érzékelhető a bányászatba, vagy a mezőgazdaságba áramló tőke, mind $1 \%$ alatti, míg a feldolgozóipar 24,8\%-ot képviselt. (Magyar Nemzeti Bank 2011)

\section{A MULTINACIONÁLIS CÉGEK JELENLÉTÉNEK HAZAI HATÁSAI}

A XXI. században a nemzetköziesedés tekintetében igen nagy szerephez jutnak a multinacionális társaságok, bankok, a multilaterális szervezetek és az Európai Unió.

Simai Mihály 2007-ben megjelent könyvében a következőt olvashatjuk: „A transznacionális társaságok nemzetgazdasági fontosságát tekintve Magyarország az ENSZ Kereskedelmi és Fejlesztési Konferenciájának kutatói által számított „transznacionalizáltsági mutató" tekintetében a fejlett országok között és az EU keretében is a hetedik helyen áll, világméretekben pedig nyolcvan ország közül a tizenkettedikek vagyunk. A transznacionalizáltsági mutató alapja a nemzetközi társaságok tőketulajdonának nagysága, az általuk termelt új érték aránya a BNT-ben, az általuk foglalkoztatottak aránya a dolgozói létszámban." (Simai 2007)

A multinacionális vállalatok hazai térnyerésének megítélése folyamatos viták kereszttüzében áll.

Vizsgáljuk meg közelebbről a hatásokat!

A magyar gazdaság világgazdasági reintegrációjának folyamatában a 90-es évek óta a külföldi szektor bővülése vált a legfontosabb tényezővé. E folyamat belső hatása is kiemelkedö.

A külföldi tulajdonú vállalatok jelentősen átformálták a magyar nagyipar szerkezetét, az exportot és importot, a technikai fejlődés mértékét és irányát, valamint a szolgáltató szektor minőségét.

Ne felejtsük el, hogy e nemzetközi vállalatok jelentősen befolyásolják az állam és $a$ 
lakosság jövedelmeit és a foglalkoztatottságot.

Nyilvánvaló, hogy a fenti folyamat révén közvetlenül ki vagyunk téve a nemzetközi piaci folyamatok hatásainak (legyen az pozitiv, vagy negativ hatás), mindez segíti a magyar gazdaság növekedését, de ezzel együtt számolnunk kell a jelentös ingadozások, a verseny és akár a spekulatív müveletek lehetséges következményeivel is.

A külföldi zöldmezös ipari beruházások által äj munkahelyek jönnek létre, ezen vállalatok túlnyomórészt exportra termelnek. Legjelentősebb képviselöjük az Audi, Opel, Suzuki, Ford, Philips, Nokia, Sony stb.

Nagyobb szakmai és társadalmi kritika fogalmazódik meg az energiaszektor és a pénzintézetek külföldiek részére történő privatizációja kapcsán. Elöbbi az áremelésekkel, utóbbi a magyar vállalkozások nehezebb hitelhez jutásával és a külföldi kontroll növekedésével magyarázható.

Az élelmiszeripari és kereskedelmi „multik”, hipermarketek átcsábítják a hazai tulajdonú kis- és közepes méretü boltok vásárlóit, mely folyamat egyértelmủen az utóbbiak ellehetetlenüléséhez vezet.

A multinacionális cégeknél a fejlesztésekről, a profit sorsáról, a beruházásokról az anyavállalat központjában születik döntés, így mi annak vagy nyertesei, vagy vesztesei lehetünk. Nyertesei lehetünk a további itthoni beruházások, regionális „alközponti” funkció betöltése révén, ugyanakkor más országban lévö leányvállalatok is „elorrozhatják” elölünk ezen lehetöségeket, ami további kockázatot jelent.

A külföldi tőke megjelenését megelőzően a hazai állami cégek tőkehiányban szenvedtek, mely megakadályozta a versenyképes müszaki-technológiai beruházások sorát.

Nyilvánvaló, hogy a nemzetközi cégek a fenti problémát saját tökeerejük, illetve alacsonyabb költséggel járó hiteleik révén megoldották, azaz a tulajdonosok biztositani tudták a vállalat átszervezéséhez, a korszerübb gépek, technológiákhoz szükséges pénzügyi és müszaki forrást is.

A hazai tapasztalatok szerint a multinacionális cégek a privatizált vállalatoknál komoly átszervezést hajtottak végre. Ez érintette az értékesitési és marketing osztályokat, az értékesítési hálózatokat, melyektöl a piacgazdasági kívánalmaknak mindinkább megfelelö, vevöorientáltabb müködést követelt meg. Alapvetően két stratégia valósult meg, nevezetesen a vállalatcsoportra jellemző standardok átültetése, vagy a helyi fogyasztói szokásoknak megfelelö marketing- és értékesítési stratégia.

A pénzügyi vonalon jellemző volt, hogy a tulajdonos által delegált munkatárs személye által egy erös kontroll jött létre, melyet a vállalat mélyebb megismerése, és a tartalékok felmérése kísért. Emellett jellemzövé vált a pénzügyi információs rendszer modernizálása, valamint az ügyviteli rendszerek kiépitése.

Számos nemzetközi cég költségei között megjelennek a know-how, a licence-k, a tanácsadói dijjak, menedzsment szolgáltatások díjai, melyek segítségével többek között az adóoptimalizálás is megvalósítható a vállalatcsoporton belül.

Az újonnan megszerzett hazai cégek termékpalettája is átalakult, mely a vállalatcsoport stratégiájához jobban igazodik. Ezáltal a kapacitás-átalakitás, -bövítés és kihasználás az egyes leányvállalatoknál hatékonyabb müködést eredményezett, esetleg ezzel kiszoritva a kisszériás gyártást.

A profiltisztitás révén egyes kiszolgáló tevékenységeket (karbantartás, takarítás, étkeztetés, biztonsági szolgálat) kiszerveztek és már külsö vállalkozóktól rendelték meg (outsourcing).

A kutatás-fejlesztés területén a kapacitást az átfogó vállalatcsoporti érdekeknek vetik alá, mely szintén újjászervezést, leépítést, vagy épp új kutatóbázis kiépítését jelenti. Egyre inkább elterjedtek az ún. regionális kutatás-fejlesztési részlegek.

A multinacionális cégek általában központosított beszerzési politikát folytatnak, 
melynek a nagy volumenủ rendelésböl adódó árkedvezménye jelentős költségelőnyt kovácsol. Ennek következtében sajnos lecserélésre kerültek a csak hazai céget kiszolgáló, korlátozott kapacitással bíró helyi háttéripari beszállitók és az import aránya ezen a téren megemelkedett. Így komoly piacvesztést szenvedtek el pl. a Lehel Hütőgépgyár, a Tungsram, a Telefongyár egykori beszállítói. Ezen túlmenően a beszállitói kör meghatározásánál a minöség, az ár és a szállitási megbizhatóság döntő fontosságú, melynek révén csak a versenyképes cégek maradhatnak bent. Utóbbiak viszont más országban müködő leányvállalatokat is kiszolgálhatnak.

A vezetöi szinteken erös az anyavállalati kontroll, a hazai vezetők önállósága kisebb, mint a magyar tulajdonú vállalatoknál.

A nemzetközi cégek jórészt fiatal, iskolázottabb munkaeröt alkalmaznak, akik rugalmasabban adaptálják az új ismereteket, és sokkal inkább terhelhetőek, mint idősebb kollégáik. Ezért a külföldi tulajdonú cégek hajlandóak magasabb bért fizetni alkalmazottaiknak, bár e munkavállalók termelékenysége kompenzálja a magasabb munkaerököltséget.

Magyarországon a multinacionális cégek révén megvalósult tudástranszfer által olyan humán erőforrás jelent meg a magyar munkaerőpiacon, ami valóban kreativ, termelékeny és versenyképes. Emellett a modern vállalatvezetési, illetve menedzsment ismeretek széles körben elterjedtek. Az idegen nyelvtudás ebben a környezetben elengedhetetlen és a szervezeti és szervezési ismeretek, valamint a vállalatirányítási rendszerek ismerete szintén széles körben elterjedt.

A külkereskedelmi mérleg vonatkozásában megfigyelhetö, hogy a külföldi tökebefektetések kezdeti időszakában romlik a külkereskedelmi mérleg, hiszen elötérbe kerülnek az anyavállalat beszállítói, ezt később kompenzálhatják a megerősödött hazai beszállítók export kiszállitásai. Az ipari technológiák nagy részénél a beruházások javarészt importból valósulnak meg, tehát ezek a típusú fejlesztések rontják a mérleget. Ezt azonban az ezekből eredő késöbbi exporttöbblet ellensúlyozni tudja. A hazai piacok megszerzésére irányuló külföldi tökebefektetéseknél az import elötérbe kerülhet föként a személygépkocsiösszeszerelés, a telefonközpont-gyártás vagy a csomagolástechnika területein.

A folyó fizetési mérleg a külföldi tỏkebehozatal révén (beruházások, fejlesztések) javul, azonban a profittranszfer - azaz a nyereség devizában történö kiutalása - révén romlik. $\mathrm{Az}$ osztalékfizetés mellett más jövedelem-kivonási technikák is megjelennek, nyilvánvalóan az adóoptimalizálás okán.

Számos ágazatban - pl. az építőiparban, kereskedelemben, élelmiszeriparban és az energiaszektorban, közmüszektorban - a külföldi töke megjelenésével komoly mértékü koncentráció jött létre, melyet a nagyobb piaci részesedés, az optimális üzemméret indukált.

Emellett több ágazatban megfigyelhető $a$ verseny növekedése, hiszen a hazánkban meghonosult a versenyszellem, mely egyrészt a hazai vállalatokat is versenyképessé tette, másrészt a verseny a vevők érdekeit is szolgálja pl. a pénzügyi szektor területén.

A hazánkba érkező külföldi menedzserek és azok családja jelentős jövedelmü fogyasztóként élik mindennapjaikat. Ezen igények kielégitése miatt kultúránkba begyürüzik a nemzetközi jelleg, mely kulturális programokban, a nemzetközi média terjedésében, speciális szolgáltatásokban testesül meg. (Antalóczi 1998) (Diczházi 1998) (Szalai 2008)

\section{A MULTINACIONÁLIS CÉGEK JÖVÖJE HAZÁNKBAN}

A müködő tőke megszerzésének gondolatára a "kevés a fóka és túl sok az eszkimó" kép jelenik meg elöttem. A '90-es években hazánk a periféria-országokra jellemző módon az olcsó munkaerő és a kormányzati támogatások révén tudta becsalogatni a külföldi tőkét. Azonban a privatizációs időszakot követően az FDI-beáramlás dinamikája csökkenni látszik, azaz stratégiát kell váltanunk a többi periférián müködö országhoz képest. 
A kivonulások is súlyosan érintik a hazai gazdaságot, gondoljunk az IBM példájára és azokra a cégekre, amelyek semmilyen kapcsolatot nem kívántak, illetve kívánnak kiépíteni a hazai vállalkozásokkal, összeszereltetik a külföldi beszállitóktől érkezö termékeket, melyet rögtön továbbitanak a külföldi piacok felé. Az ilyen gyökeret nem eresztő cégek általában bérlik az üzemcsarnokot, sôt a munkaerö jelentös részét is, ezáltal pár hét alatt könnyedén telephelyet tudnak váltani.

Mindenképpen a magasabb hozzáadott értéket létrehozó, illetve a hazai beszállitókat és képzett munkaeröt preferáló tevékenységeket kell „helyzetbe hoznunk”, föként a kutatásfejlesztésnek kell kulcsszerephez jutnia.

Ez javarészt megóvhat minket a kitelepülésektöl, bár biztosra menni ebben az esetben sem lehet, hiszen a profitorientáciỏ lebeg a nemzetközi cégek stratégiai döntéshozóinak szeme elött. A szolgáltató- és logisztikai központok is kitörési pontot jelenthetnek hazánk számára, bár napjainkban ez is óriási versenyt jelent.

A gyökértelen nemzetközi vállalatok mellett meg kell említenünk a másik pólust is, hiszen vannak javarészt olyan vállalatok, melyek $K+F$ tevékenységet is folytatnak hazánkban, ilyen például a General Electric, Sanofi Chinoin, Nokia, Siemens, Audi, Knorr-Bremse, Flextronics, Michelin, Unilever stb. (Ivicz et al. 2004)

Új befektetóként jelent meg 2009-ben Kecskeméten a Mercedes, mely 2012-ben kezdi magyarországi termelését és reméljük, hogy a fenti körhöz is csatlakozni fog.

A hazánkba betelepült high-tech iparágban tevékenykedő nemzetközi cégek esetében beruházási döntéseinek meghozatalakor az iparban lévö know-how is befolyásoló tényezó volt. Az pedig még nagyobb elörelépés, amikor a magyarországi telephelyeken, a gyártóhely kategórián túllépve fejlesztési és tesztközpontok létesülnek. Erre kiváló példa az egri ZF leányvállalata, mely tudományos partnerévé választotta a Miskolci Egyetemet és a Budapesti Müszaki Egyetemet. Ebben az esetben is a cég irányt szab a kutatásoknak, és a kutatási eredmények azonnal berobbanhatnak a technológiafejlesztés területére, mely visszahat hazánk exportképességére, a gazdaság növekedésére. Ennél jobb win-win kapcsolatot nehezen tudok elképzelni. (Bogdán 2007)

\section{6. ÖSSZEFOGLALÁS}

A téma feldolgozása során arra a következtetésre jutottam, hogy a magyar gazdaság jövöbeni fejlődésének szempontjából elengedhetetlen a tőkevonzó képességét javítani.

Ennek érdekében az alábbiakat tartottam fontosnak kiemelni:

- Nagyobb figyelmet kell kapniuk a magasabb hozzáadott értékü tevékenységeknek.

- A szolgáltatásokra való átállás mindenképp új helyzetet teremt, hiszen ez a telephelyi elönyökröl való gondolkodást is megváltoztathatja. Ezáltal elötérbe kerülhet a magas fokú szakképzettség és a nyelvtudás.

- A külföldi töke feldolgozóiparba történö áramlása akkor valósulhat meg sikeresen, ha megfelelö szolgáltató háttér jön létre.

- Tovább kell fejleszteni a közlekedési és hírközlési infrastruktúrát.

- Új területekre, magasabban kvalifikált munkaeröt igénylö tevékenységekre kell szakosodni, például megcélozhatjuk a nemzetközi vállalatcsoportokon belüli szolgáltató, pénzügyi, számviteli központok hozzánk történő telepítését.

- Növelni kell a szubvenciók hatékonyságát. Emellett a területfejlesztésre is gondot kell fordítani, ha el akarjuk kerülni, hogy a támogatások megszünésével a cégek továbbálljanak.

- Vissza kell szoritani a korrupciót.

- Nagyobb figyelmet kellene szentelni a tökevonzás puha tényezőinek, figyelembe kell venni, hogy az adott terület milyen mennyiségi és minöségi adottságokkal 
rendelkezik például az életminöség, az oktatás és a kultüra területén.

Ezáltal nem csupán hosszú távú tőkeimporthoz, hanem folyamatos tudástranszferhez is juthat Magyarország.

Emellett szükség van a nemzetközi kitettségünkböl eredő kockázat minimalizálására is.

A hazai cégek felzárkóztatása óriási kihivást jelent, de egy stratégiailag átgondolt, jól szervezett támogatási rendszerrel ezek a vállalatok a nemzetközi cégek komoly, nagy súlyú beszállítóivá, sőt akár versenytársaivá, vagy a hazai piac jelentős szereplöivé válhatnak, nem csak magyar, hanem nemzetközi viszonylatban is.

A mai magyar gazdaság kiemelt kérdése az, hogy a rendelkezésünkre álló hazai humán tökét hogyan tudjuk kiaknázni mind a nemzetközi, mind pedig a magyar tulajdonban lévő cégek javára, amellett, hogy a mind anyagilag, mind pedig szakmailag megbecsült alkalmazotti réteg, a menedzsment, az adóbevételek révén az államháztartás és ezáltal, közvetetten a magyar társadalom elégedett lehessen. Tisztában vagyok azzal is, hogy nem minden külföldi cég hagyott, illetve hagy maga mögött sikertörténeteket Magyarországon, éppen ezért a kormányzat felelőssége is ennek a kockázatnak a minimalizálása, például azáltal, hogy a külföldi cégeket ösztönözni kell a hosszú távú maradásra, és a magyar beszállítók igénybevételére.

Öszinte reményeimnek adok hangot akkor, amikor elképzelek egy olyan jövőt, ahol a hazai közvélemény tudatában a multinacionális cég fogalma nem negatív érzéseket, hanem leginkább a bizalmat, a fejlödési lehetőségeket, a követendő mintát, a hazai gazdaság fejlödését, a kulturális sokszínúséget jelenti majd.

\section{IRODALOMJEGYZÉK}

Antalóczy K. (1998): A multinacionális cégek szerepe a világgazdaságban, Kelet-KözépEurópában és Magyarországon. Korunk. 3. évf. IX/3. www.hhrf.org/korunk/9803/3k02.htm (2011.02.20.)

Bogdán Z. (szerk.) (2007): Multinacionális cégek hatása a kutatás-fejlesztésre - Az együttmüködés kényszer és lehetöség. Gazdasági Tükörkép magazin. 2007/4. http://www.gtm.hu/magazin/multinacionalis-cegek-hatasa-a-kutatas-fejlesztesre (2011.02.20.)

Diczházi B. (1998): Tapasztalatok és tanulságok. Külföldi müködőtöke-befektetések Magyarországon. Korunk. 3. évf. X/11. www.hhrf.org/korunk/9811/11k27.htm (2011.02.20.)

Erdős T. (2003): Fenntartható gazdasági növekedés. Akadémiai Kiadó. Budapest.

Ivicz M. - Katona K. - Schlett A. (2004): Vonzó-e Magyarország a müködö tőke számára? In: Botos Katalin: Pénzügyek a globalizációban. JATEPress. Szeged.

Magyar Nemzeti Bank (2011): Közvetlen tőkebefektetések (idősorok). A nem rezidensek magyarországi közvetlen tőkebefektetés (részvény, egyéb részesedés és újrabefektetett jövedelmek) állományának országonkénti megoszlása. www.mnb.hu/Statisztika/statisztikaiadatok-informaciok/adatok-idosorok/vii-kulkereskedelem/mnbhu_kozetlen_tokebef (2011.02. 20.)

Simai M. (2007): A világgazdaság a XXI. század forgatagában. Akadémiai Kiadó. Budapest.

Szalai E. (2008): A multinacionális vállalatok, valamint társadalmi, gazdasági és politikai kisugárzásuk Magyarországon. Országos Tudományos Kutatási Alapprogramok. www.otka.hu/index.php?akt_menu=3713 (2011.02.20.) 